\title{
Erratum: Multimodal stimulus coding by a gustatory sensory neuron in Drosophila larvae
}

Lena van Giesen, Luis Hernandez-Nunez, Sophie Delasoie-Baranek, Martino Colombo, Philippe Renaud, Rémy Bruggmann, Richard Benton, Aravinthan D.T. Samuel \& Simon G. Sprecher

Nature Communications 7:10687 doi:10.1038/ncomms10687 (2016); Published 11 Feb 2016; Updated 14 Mar 2016

The affiliation details for Martino Colombo, Rémy Bruggmann and Richard Benton are incorrect in this article. The correct affiliations for these authors are listed below.

Martino Colombo, Rémy Bruggmann

Interfaculty Bioinformatics Unit and Swiss Institute of Bioinformatics, University of Berne, Berne 3012, Switzerland.

Richard Benton

Faculty of Biology and Medicine, Center for Integrative Genomics, University of Lausanne, Genopode Building, Lausanne CH-1015, Switzerland.

This work is licensed under a Creative Commons Attribution 4.0 International License. The images or other third party material in this article are included in the article's Creative Commons license, unless indicated otherwise in the credit line; if the material is not included under the Creative Commons license, users will need to obtain permission from the license holder to reproduce the material. To view a copy of this license, visit http://creativecommons.org/licenses/by/4.0/
} 